\title{
Symphony no. 6 in F major, 'Pastoral', by Ludwig van Beethoven, honorary member of the Philharmonic Society in Ljubljana
}

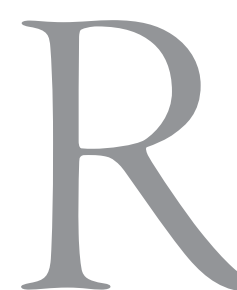

adical changes triggered by the French revolution and the socio-political events tied to it fundamentally altered the previous power balance in Europe and gradually influenced far-reaching shifts in musical theory and practice. In I805, for instance, Napoleon's conquest of Vienna resulted in the first version of Beethoven's Fidelio being withdrawn from the programme after only three performances. Befitting the new military situation, a certain conformity of the audience's musical taste may be perceived, best reflected in the attraction to many of the then highly popular marches, whose fame rapidly diminished soon after. These usually paint, in a most vivid fashion, victorious battles on land or at sea. Even Beethoven, for example, in the composition Wellington's Victory, or the Battle of Vittoria (Wellingtons Sieg, oder die Schlacht bei Vittoria, 1813), had succumbed to the temptation of satisfying the general taste of the public. ${ }^{.}$Similarly, also in the setting to music of the military song Österreich über alles by Heinrich Joseph von Collin - its Slovenian arrangement with a changed meaning (Estrajh za vse) was prepared by Valentin Vodnik - he attempt-

I Carl Dahlhaus, Die Musik des Ig. Jahrhunderts: Neues Handbuch der Musikwissenschaft, no. 6 (Laaber: Laaber Verlag, 1996), 64 ed to support the resistance against the Paris occupiers. ${ }^{2}$ After the significant continental clashes of the $\mathrm{I}^{\text {th }}$ century, the mobilising power of music had already been well tested in a time of wars between Napoleon and the coalitions of European forces.

The Habsburg monarchy, in particular, was becoming an ever more influential controller of musical events and was increasingly assuming the leading position among European musical centres. The riches and splendour of the Habsburgs attracted numerous musicians from across Europe, among them Beethoven, who undoubtedly left the most ground-breaking and far-reaching mark on symphonic creativity in the $19^{\text {th }}$ century with his symphonies. As he began creating his first symphonic work in 1799 , a century exceptionally productive for such creation was coming to an end. Moreover, the symphonies or their indi-

2 Ludwig van Beethoven, 'Skizzenblatt zum Wehrmannslied "Österreich über alles” von Heinrich Joseph von Collin Unv I8, zu “Mignon” op. 75,' Sammlung H. C. Bodmer, HCB Mh 79, Beethoven-Haus Bonn, https://www.beethoven.de/sixcms/detail.php?id=\&template=dokseite_digitales_archiv_de\&_ dokid $=$ ha: $w$ m225\& seite $=$ I

3 Igor Grdina, 'Aktivizem, meditacija in kontemplacija: glasba in prva svetovna vojna,' Muzikoloski zbornik 53, no. 2 (2017): 6. 
vidual movements were until then mainly performed merely as part of a mixed programme in which they would normally alternate with overtures, opera arias, oratorio choruses, Liedertafel quartets, and bravura solo improvisations. Such a colourful structure is revealed by the concert programmes of different philharmonic societies that started to appear through Europe at the end of the $18^{\text {th }}$ and the beginning of the $19^{\text {th }}$ centuries, and effectively encouraged performances of symphonic literature. Having a particularly venerable place among them with its founding date of 1794 is the Ljubljana Philharmonic Society (Philharmonische Gesellschaft), the function of which is especially closely bound up with Beethoven's legacy. One of the most notable cases of such a mixed programme is the concert prepared by Beethoven on 22 December 1808 at the famous Viennese theatre Theater an der Wien. In the programme, there were his works alone, among them Symphonies no. 5 in $C$ minor and no. 6 in F major ('Pastoral'), the Concerto for piano and orchestra no. 4 in $G$ major, the Fantasia ('Choral Fantasy') for piano, choir and orchestra, the soprano concert aria $A$ h, perfido etc. ${ }^{4}$

Therefore, it was precisely because of the works of the great German composer that the symphony was increasingly becoming a central musical genre of symphonic music concert programmes. In this way, his rounded opus of nine symphonies with an expressively intensifying and radically individualising of style, when compared to exceedingly quantitative symphonic opuses of his predecessors, shows an entirely new view of symphonic creativity. In his symphonies, Beethoven was thus continuously searching for new formal and instrumental solutions, which had an effect on the audience as the products of a genius, soon worshipped as the pre-eminent composer of his nation. ${ }^{6}$

4 David Wyn Jones, 'The Concert of 22 December 1808', in David Wyn Jones, Beethoven: Pastoral Symphony (Cambridge: Cambridge University Press, 1995), I-2.

5 Peter Schnaus, ed., Europäische Musik in Schlaglichtern (Mannheim, Wien, Zürich: Mayers Lexikonverlag, 1990), 313.

6 Matjaž Barbo, Simfonija prve polovice Ig. stoletja (Ljubljana: Oddelek za muzikologijo Filozofske fakultete, 2008), I4-5.

\section{Symphony no. 6 in F major (op. 68), 'Pastoral'}

In 1809 , upon the publishing of the parts of the Symphony no. 6 in F major, he wrote the famous words: 'More the expression of feeling than painting' (Mehr Ausdruck der Empfindung als Malerey). Emphasis stressed by the composer with the mentioned thought of the expression of feelings before painting coincided with the dominant aesthetic view of his time, more expressively directed mainly at the reflection of feelings, at the 'poetical', supposedly shines through from behind the very sound image of the work.7 The purport of the Pastoral Symphony, therefore, is not just a sort of an image of Plato's copying a copy (Malerey in Beethoven's words), which the art serves as a hidden carrier of an idea hidden in nature, but rather the carrier of the idea itself, it is its embodiment (Ausdruck der Empfindung). ${ }^{8}$

As a consequence, it is precisely from the viewpoint of exceeding and breaking with the mimesis principle (i.e. copying that which exists in nature) that Beethoven's Sixth Symphony still holds a quite special place in Beethoven's opus. Even though it could be interpreted as Beethoven's expression of love for the countryside, its 'pastorality' shows much more. It is mostly about the composer's connectedness with the early romantic ideals. Its poetic nature thus first identifies with the then topical aesthetic normative system that was setting, as it seems, an increasingly binding paradigm for all the arts. Through it, the call retour a la nature of the French Enlightenment was again coming to the foreground as an appeal to the idyll of the shepherd's life - a symbol of cohabitation with nature. This symbolises an untarnished primality, genuineness, calmness, harmony, among other aspects. It was what the romantic artist longed for in his world-weary inner split that was driving him away from the 'cruel' real world.'

Barbo, Simfonija prve polovice 19. stoletja, I8

8 Matjaž Barbo, Simfonija v Ig. stoletju: zadrege zvrsti (Ljubljana: Znanstvena založba Filozofske fakultete, 20ı2), 20.

9 Barbo, Simfonija prve polovice Ig. stoletja, I8. 
In his sketches to the Pastoral Symphony, Beethoven wrote that '[the] hearers should be allowed to discover the situations' (Man überlässt es dem Zubörer, die Situationen auszufinden) that his music depicts within, but was aware at the same time that, 'all painting in instrumental music is lost if it is pushed too far' (Jede Mablerei, nachdem sie in der Instrumentalmusik zu weit getrieben, verliert $).{ }^{10}$ Even when the purport of the Sixth Symphony seems clearly recognisable, the composer is in some way communicating to the listener that it is only an appearance, behind which the true meaning is hiding.

Beethoven wrote the work from the summer of 1807 to the autumn I 808 in the countryside surroundings of Heiligenstadt and Baden near Vienna. The symphony thus came into existence in highly turbulent times, three years after the Habsburg capital bowed to the onset of $\mathrm{Na}$ poleon's army. The hard blow struck Beethoven in 1802 by the advancing loss of his hearing was growing increasingly obvious over the years, but partial deafness, along with some personal problems, often escalated into conflict with those close to him. Therefore, the composer's increasingly frequent retreats into nature and admiring its beauties, are likely to have contributed to his inspiration and preparation for the creative process, and should come as no surprise.

The Pastoral Symphony was first performed under the composer's lead in the famous public concert of 22 December 1808 at Theater an der Wien. Over four hours of music were supplemented by Beethoven with some piano improvisations. The composer Johann Friedrich Reichardt later remembered the event:

'There we continued, in the bitterest cold, too, from half past six to half past ten, and experienced the truth that one can easily have too much of a good thing - and still more of a loud thing.' (Da haben wir denn auch in bitterster Kälte von halb sieben bis halb elf ausgehalten, und

Io Thomas-San-Galli and Wolfgang Alexander, Ludwig van Beethoven (Berlin: Dearbooks, 2014), 250. die Erfahrung bewährt gefunden, daß man des Guten und mehr noch des Starken leicht zu viel haben kann. $)^{\text {II }}$

In such an atmosphere, the symphony certainly could not provoke excessive enthusiasm.

Because of its extra-musical clues, long after its first performance, the work stirred up the imagination, mainly that of supporters of the so-called programme music. Furthermore, it is worth mentioning that 'pastoral' has been, from ancient times onward, an essential element in art. In the Renaissance and Baroque era, it strongly influenced painting as well as literature and other humanist disciplines. In music, it was first prevalent in the madrigal, German shepherd plays, masses, and Italian pastoral opera. However, it was also present in instrumental music, most distinctively in the $18^{\text {th }}$ century: from Vivaldi's violin concertos in the collection The Contest between Harmony and Invention (Il cimento dell'armonia e dellinventione), to Haydn's oratorio The Seasons, and eventually the pastoral symphonies in Handel's Messiah and Bach's Christmas Oratorio. ${ }^{12}$ In a wider context, Beethoven's Sixth is strongly anchored in the above-mentioned pastoral genre, idealising the imaginary image of harmonic life with nature, wherein a fantasy of ideal inter-human relations unravels. ${ }^{13}$ Moreover, the pastoral theme later also inspired numerous symphonists, among them Alexander Konstantinovich Glazunov in Symphony no. 7 in Fmajor and Ralph Vaughan Williams in his Third symphony.

In Beethoven's score, alongside the so-called characteristic elements of 'pastoral' music, we find many hints of the world of pastoral. Among most evident examples of these 'depictions' are onomatopoetic imitations of the singing of nightingale (Nachtigal), quail (Wachtel), and cuckoo (Kuckuck) in the second, and the imitation of a summer storm with thunder in the fourth movement of the symphony. Also contrib-

I Peter Gülke, “...immer das Ganze vor Augen”: Studien zu Beethoven (Stuttgart, Weimar: Metzler, Bärenreiter, 2000), I39.

I2 Wyn Jones, 'The Pastoral Tradition,' in David Wyn Jones, Beethoven: Pastoral Symphony (New York: Cambridge University Press, 1995), 14-6.

I3 Barbo, Simfonija prve polovice ig. stoletja, I8. 
uting to the pastoral atmosphere are perfect fifths, reminiscent of bagpipe fifths, ostinatos, use of 'rustic' instruments, represented for example by the oboe in the third movement, characteristic repeating thirds etc. ${ }^{14}$ Once again, it is necessary to emphasise that the idyllic world of nature carries foremost a symbolic meaning in Beethoven's pastoral context. Therefore, despite numerous associations with concrete sounds from nature, unmistakable images of bird song or storms, in its essence, the Sixth does not signify 'painting', but is above all an 'expression of feelings', expression of romantic longing for pastoral harmony. ${ }^{\text {st }}$

With five movements, the Pastoral is the most unusual of all Beethoven's symphonies. At first glance, it seems to be an unconventional number, defying the then prevailing four-movement standardisation of the symphony in favour of the genius of the rising Romanticism, yet still, the true background of the five movements is hiding in the composer's cyclical understanding of the symphony. To understand this claim, somewhat more detailed insight into the structural laws of the Pastoral Symphony is required.

Prior to publishing the score, Beethoven had been contemplating for several years how to title individual movements. Eventually, he decided upon the following:

I. Awakening of cheerful feelings on arrival in the countryside (Erwachen heiterer Empfindungen bei der Ankunft auf dem Lande);

2. Scene by the brook (Szene am Bach);

3. Merry gathering of countryfolk (Lustiges Zusammensein der Landleute);

4. Thunder-Storm (Gewitter-Sturm) and

5. Shepherd's song. Cheerful and thankful feelings after the storm (Hirtengesang. Frohe und dankbare Gefüble nach dem Sturm).

I4 Ibid., I9.

I5 Ibid.
These five quasi-bucolic pictures were actually joined by the composer into three movements since the third, fourth, and fifth are performed without breaks.

The first movement (Allegro ma non troppo) is written in sonata form with an extended coda. The introductory theme itself contains three elements for further development. This light thought, in a kind of quasi-monothematic sense, marks the entire movement, since the rest of motivic-thematic material only non-compellingly completes it. In this way, the mood is thoroughly calm and pleasant.

The second movement (Andante molto mosso) with its fluently ethereal quality takes us to the scene by the brook. It is written in sonata form with two themes that do not contrast with each other explicitly. It is concluded with the notable imitation of birds singing, in which we hear the 'singing' of the nightingale (flute), sounding of the quail (oboe) and cuckoo (clarinet). In 1823 , during a walk in the forest near Heiligenstadt, the already completely deaf composer is said to have told his friend Anton Schindler:

This is the spot on which I wrote the scene at the brook, with yellow-hammers calling over my head, and quails, nightingales, and cuckoos. Helping me all round. (Hier habe ich die Szene am Bach geschrieben, und die Goldammern da oben, die Wachteln, Nachtigallen und Kuckucke ringsum haben mitkomponiert. ${ }^{16}$

However, it seems that it is not so much an actual description, but yet another in a line of idealisations of the later Romantic imagination.

The third movement (Allegro) is a witty, somewhat grotesque farmers' dance in which two related themes exchange above the pedal tone. Perhaps the composer deemed that best suited for this was scherzo form, to which Beethoven was able to give a characteristic feature with various tiny imitations of country musicianship. Thus typical of the movement is a 'dilettantish' accompaniment with tonic and dominant; and a

I6 George Grove, Beethoven und seine neun Symphonien; Deutsche Bearbeitung von Max Hehemann (London: Novello, 1906), 196. 
persistent solo melody for the oboe convincingly imitates the shepherd's flute. The shoe slapper (Schuhplattler) dance sounds like a scherzo's trio. Everything repeats itself twice, and just as the first part is about to repeat itself for yet the third time, a menacing storm with raging tempest announces a musical-dramaturgical landmark.

The fourth movement (Allegro) puts it in the centre of what is taking place, since it most realistically 'paints' thunder and lightning, a shower and, finally, fine rain. For the time, Beethoven bestowed the movement with a virtuoso, although not entirely peculiar, appearance of the mentioned weather phenomena that had already often been a subject of musical illustrations. A dramatic flow is followed by an expanded instrumentation, as Beethoven adds two trombones and piccolo to the orchestration. Hector Berlioz, like many other supporters of programme music, found in the Pastoral the ideal precursor to his programme symphonies, and has written about the movement:

Listen to these gusts of wind heavy with rain, the muffed roaring of the basses and the shrill whistling of the piccolos, warning of a dreadful storm about the break. [...] This is no longer mere wind and rain - it is a terrifying cataclysm, a universal flood, the end of the world. ${ }^{17}$

The music continues without a break into the finale (Allegretto). Formally, this movement cannot be entirely uniquely understood: it resembles an expanded rondo with a coda. Although the finale is mostly based on the first theme, the second is soon recognisable as well - it resembles a motif from the beginning of the symphony - giving Beethoven's 'idyllic landscape' symmetrical shape. Also worth pointing out is the coda, seeming to represent an internalised peak of the composition, chorale or, better put, a vocally conceived part of the composition. The wording of the latter, as a sort of thanks for creation based on a notation from the sketch for the last movement (Ausdruck des Dankens. Herr, wir

17 Hector Berlioz, The Art of Music and Other Essays: A Travers Chants (Bloomington, Indianapolis: Indiana University Press, 1994), 23-4. danken Dir), could read: 'We thank Thee, almighty God!' (Wir danken Dir, allmächtiger Gott!). ${ }^{18}$

The entire musical course of the Pastoral symphony is thus subordinate to the sonata cycle, whereas the storm movement functions as a development section of a sort, and the finale takes the place of a quasi-reprise. The transfer of a unified dramaturgical arc onto a four-movement work was an idea taken over after Beethoven by many symphonists in the $19^{\text {th }}$ century. Also deriving from it is the inclusion of an added fourth movement that carries dramatics, otherwise a property of symphony first movements. The latter was surprisingly renounced by Beethoven in the introductory movement of the Sixth. Thus, it is also obvious in this regard that the composer is realising the aspiration for a cyclic rounding-up of movements, which develop into a harmonic idyll, romantically illustrated through the calming of the storm and clearing up. ${ }^{19}$

\section{Beethoven as honorary member \\ of the Philharmonic Society in Ljubljana}

It was only the concert activity of the Ljubljana Philharmonic Society, founded in 1794, that spurred acquaintance in our land with the most contemporary symphonic literature, and powerfully strengthened, in practically all the segments, the progressiveness of symphonic music in lands between the Alps and the Adriatic. We find numerous local and foreign musicians among honorary members of the society. Among the first, the pioneer of symphonism in Slovenia, František Josef Benedikt Dusík, ${ }^{20}$ and the later ones, certain musical principals of the Society as well, amid them worth pointing out Anton Nedvěd, Josef Zöhrer, and Hans Gerstner. Other than that, the Philharmonic Society strengthened its reputation primarily with the membership of some most important

I8 Grove, Beethoven und seine neun Symphonien, 205.

I9 Barbo, Simfonija prve polovice Ig. stoletja, 21.

20 Matjaž Barbo, František Josef Benedikt Dusik: The Biography of an Eighteenth-Century Composer (Wien: Hollitzer Wissenschaftsverlag, 2011), 46. 
foreign composers and musical performers (among them Joseph Haydn, Niccolò Paganini, Johannes Brahms). ${ }^{21}$ With them, the Philharmonic Society reaffirmed throughout $19^{\text {th }}$ century its high-set goals, especially ambitiously realised in the beginning of its path, in the period of classicism. In view of significant ambitions of the Society, it was almost obvious that the latter would also try to attempt to draw into its ranks the most important representative of this period - Ludwig van Beethoven.

The first preserved music catalogue (Musicalien-Catalog) 2 $^{22}$ of the Philharmonic Society from the years 1794-1804 shows there had to be a period of successful operation prior to 1808 , when the idea of inviting Beethoven as an honorary member of the Society first arose. Among Beethoven's compositions often placed in the Philharmonic Society's concert programmes, they performed near the start of the century the first two Beethoven's symphonies, Piano Concerto no. I in C major, and certain chamber works.

However, we can only get a clearer picture of the concert situation from 1816 onward, as the concert programmes, except for a single one from I8I reproduced in Emil Bock's publication, ${ }^{23}$ have only been partially preserved since $1816 .^{24}$ Listed by Bock as the opening work of the academy, ${ }^{25}$ on a programme on 8 January I 81 I, is a big symphony by Ludwig van Beethoven (Eine grosse Symphonie von Herrn van Beethoven). ${ }^{26}$

2I Ivan Klemenčič, 'Častni člani ljubljanske Filharmonične družbe,' in Evropski glasbeni klasicizem in njegov odmev na Slovenskem, edited by Dragotin Cvetko and Danilo Pokorn (Ljubljana: SAZU, 1988a), 123-34.

22 Musicalien-Catalog der Philharmonischen Gesellschaft in Laibach Zum Gebrauch für auswärtige Herren Mitglieder dieser Gesellschaft Nro I Seit I. Nov. 1797 bis letzten Juni I804 / Wird halbjährig fortgesetzt. See NUK, archive of the Philharmonic Society.

23 Emil Bock, Die philharmonische Gesellschaft in Laibach (Laibach: Kleinmayr \& Bamberg, 1902), 13 .

24 In the article, we rely on concert programmes kept in the Music collection of the National and University Library in Ljubljana. See NUK, archive of the Philharmonic Society, folder Concert programs.

25 This is how solemn events with cultural program were named at the time.

26 Bock, Die philharmonische Gesellschaft, $\mathrm{I}_{3}$.
Which symphony that was cannot be claimed with certainty. It appears to have been the Eroica. ${ }^{27}$

Relevant sources are also lacking regarding the first performance of Beethoven's Sixth Symphony in our parts. Thus, despite exhaustive studies shedding light on the composer's ties to Ljubljana ${ }^{28}$ the chronology of the first performance of Pastoral in Slovenia is not entirely explained. Nevertheless, the most prominent researchers of Beethoven's symphonic performance in Ljubljana assume that Symphony no. 6 in F major was first performed here on 28 February $1818 .{ }^{29}$ Music catalogues of the Ljubljana Philharmonic Society, however, reveal that only the first two movements of Pastoral Symphony were performed in the Society's concerts on II April I 823, which was followed in May 1823 by a performance of the entire symphony. ${ }^{30}$

Moreover, they wanted to elect Beethoven an honorary member of the Ljubljana Philharmonic Society in 1808 , which is the year of the origin of the Pastoral Symphony. Indicative of the cause for Beethoven's initial non-election is the report by the Vienna-based doctor, Anton Schmitt, also an honorary member of the Ljubljana Philharmonic Society. He was

27 Klemenčič, ‘Častni člani ljubljanske Filharmonične družbe,' ${ }^{2} 23$.

28 Primož Kuret, Ljubljanska filharmonična družba: 1794- Igrg (Ljubljana: Nova revija, 2005), 47-55. See also: Ivan Klemenčič, 'Beethovnova 6. simfonija in zveze z Ljubljano, in Zbornik Narodne in univerzitetne knjižnice: II, nija in zveze z Ljubljăo, in Zbornik Narodne in univerzitetne knjiznice: II,
edited by Branko Berčič, Jože Munda, Maks Veselko, and France Vurnik (Ljubljana: NUK, 1978), 91-9; Ivan Klemenčič, Slovenska filharmonija in njene predhodnice (Ljubljana: Slovenska filharmonija, 1988b), 32; Ivan Klemenčič, Slovenska glasba v evropskem okviru (Celje: Celjska Mohorjeva družba, 2008), III-30; and Klemenčič, 'Častni člani ljubljanske Filharmonične družbe,' 228 .

29 Klemenčič, 'Beethovnova 6. simfonija in zveze z Ljubljano', 96. See also: Kuret, Ljubljanska filharmonična družba, 49; Sieghard Brandenburg, Secbste Symphonie F-Dur Opus 68. Sinfonia pastorale. Faksimile nach dem Autograph BH 64 im Beethoven-Haus Bonn mit einem Kommentar von Sieghard Brandenburg (Bonn: Beethoven-Hauses, 200ob), 27; and Jens Dufner, Beethoven Werke, Symphonien III (München: G. Henzle Verlag, 2013a), 277.

30 Sara Železnik, Koncertni sporedi Filharmonicne družbe $1816-1872$ (Ljubljana: Oddelek za muzikologijo Filozofske fakultete Univerze v Ljubljani, 20I2b), $82-3$. 
appointed to intercede with the composer, but eventually sent word to Ljubljana that Beethoven is 'too moody and not obliging enough' (Beethoven hat ebenso viele Launen, als wenig Dienstfertigkeit). ${ }^{31}$ In the mentioned letter, Schmitt also disclosed to the direction of the Society that he would rather assign his vote to the excellent pianist and composer Johann Nepomuk Hummel. It appears the direction wavered at the time between inviting Beethoven or Hummel, who later never became a member of the Society. They most likely estimated that inviting Beethoven, already perceived at the time as one of the most famous composers alive, would prove too risky. Thus the Society did not initially decide upon an invitation. Only in I8I9 did the direction of the Ljubljana Philharmonic Society then, through intervention by Viennese magistrate councillor Mathia von Tuscher, hand the composer a diploma of honorary membership, dated Is March I819, along with the society statute and membership list. ${ }^{32}$ We quote the letter in its entirety:

Die hiesige philharmonische Gesellschaft, deren Zweck Verfeinerung des Gefübls und Bildung des Geschmacks im Gebiete der Tonkunst ist, mußte bei ibrem ratlosen Streben, dem Vereine nach innen und ausen auch durch zweckmäßige Wabl neuer Glieder, immer mehr Gehalt, Solidität und Zierde zu geben, allgemein von dem Wunsche durchdrun-gen werden, die Zahl ihrer Ehrenmitglieder durch Eu. Wohlgeb. geziert zu wissen. Das Organ dieser Gesellschaft, die unterzeichnete Direktion, erfüllt, den allgemeinen Wunsch der Gesellschaft realisirend, diesmal ibre an-

3I 'In this regard, I would only vote for the last one, Hummel's son who works with the ruling bandmaster Nikolaj Esterhazy as second bandmaster (Haydn is first). Otherwise, Beethoven is too moody and not obliging enough.' (Ich meines Theils würde in dieser Rücksicht mein votum blos für den letzten, nämlich Hummels Sohn geben, der bei dem regierenden Fürst Niklas Esterhazy 2. Hofkapellmeister ist (Haydn ist der erste). Beethoven hat eben so viele Launen, als wenig Dienstfertigkeit.) Friedrich Keesbacher, Die philharmonische Gesellschaft in Laibach seit dem Jahre ihrer Gründung I7oz bis zu ibren letzten Umgestaltung I 862. Eine geschichtliche Skizze (Laibach, I862b), 50.

32 Keesbacher, Die philharmonische Gesellschaft in Laibach, 50. genehmste Pflicht, indem sie E. W. durch die Ernennung zum Ehrenmitgliede den vollsten Beweis ihrer tiefsten Verehrung anzunehmen ersuchet und zugleich ein Exemplar der Statuten und des Verzeichnis ses der dermaligen Mitglieder hier beischließt. Laibach am I5. März 1819.33

Beethoven afterwards thanked the society through the letter of 4 May I819 in which he wrote that he can appreciate the recognition for his trifling merits in musical art, acknowledged to him by the Ljubljana Philharmonic Society by this honouring.

In the letter he wrote:

An die Philarmonische Gesellschaft in Laibach.

Den EhrenVollen Beweiß, welchen mir die würdigen Mitglieder der Philarm. Gesellschaft als Anerkennung meiner geringen Verdienste in der Tonkunst dadurch gegeben haben, daßsie mich zu ihrem Ehren Mitgliede erwählt haben, und mir das Diplom darüber durch Hr. MagistratsRath v. Tüscher haben zustellen laßen, weiß ich zu würdigen, und werde zu seiner Zeit als einen Beweiß dieser meiner würdigung ein noch nicht öffentlich erschienenes Werk durch obgedachten Herrn M.R. v. Tüscher an die Gesellschaft die Ehre haben gelangen zu laßen. Wo übrigens die Gesellschaft meiner bedarf, werde ich jederzeit mich dazu bereit finden laßen -

33 'The Philharmonic Society here has, with the intention of improving the perceiving and educating taste in the field of music, through tireless effort, had to give the society within and outside, also with thoughtful choice of new members, an ever greater weight, solidity and pride, to be imbued with the desire to decorate the number of honorary members with your worship. The signed direction as competent agency of the society, at this time through realisation of its general wish, fulfils the most pleasant duty by naming your worship honorary member and requests the admission of this proof, full of its profoundest admiration. An example of statutes and list of members to-date is added. Ljubljana, is March i8ı9.' Ibid. 


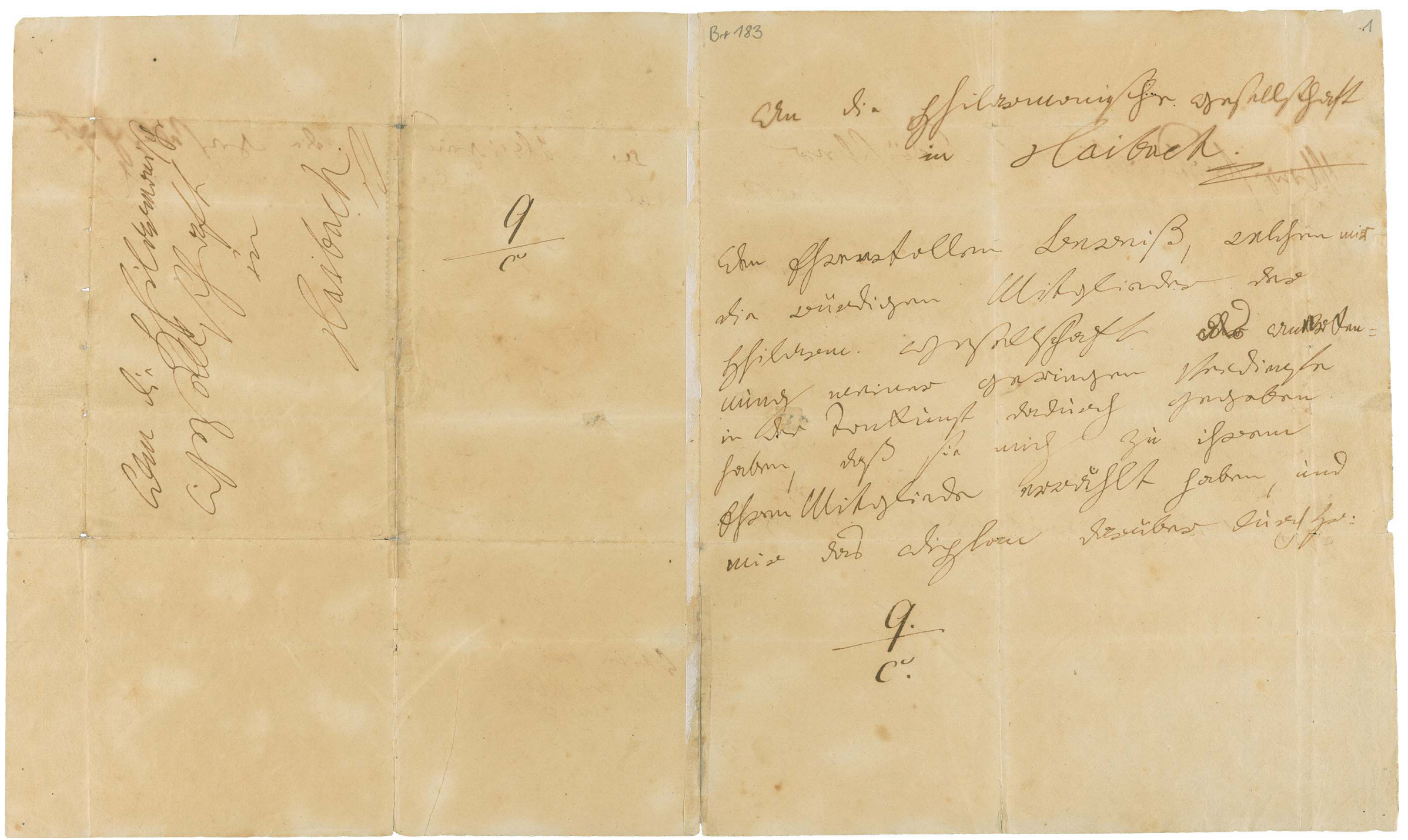

Ludwig van Beethoven, Letter to Philharmonic Society in Ljubljana, Vienna, $4^{\text {th }}$ May I8Ig, Autograph, Beethoven-Haus Bonn, Sammlung H.C. Bodmer. 


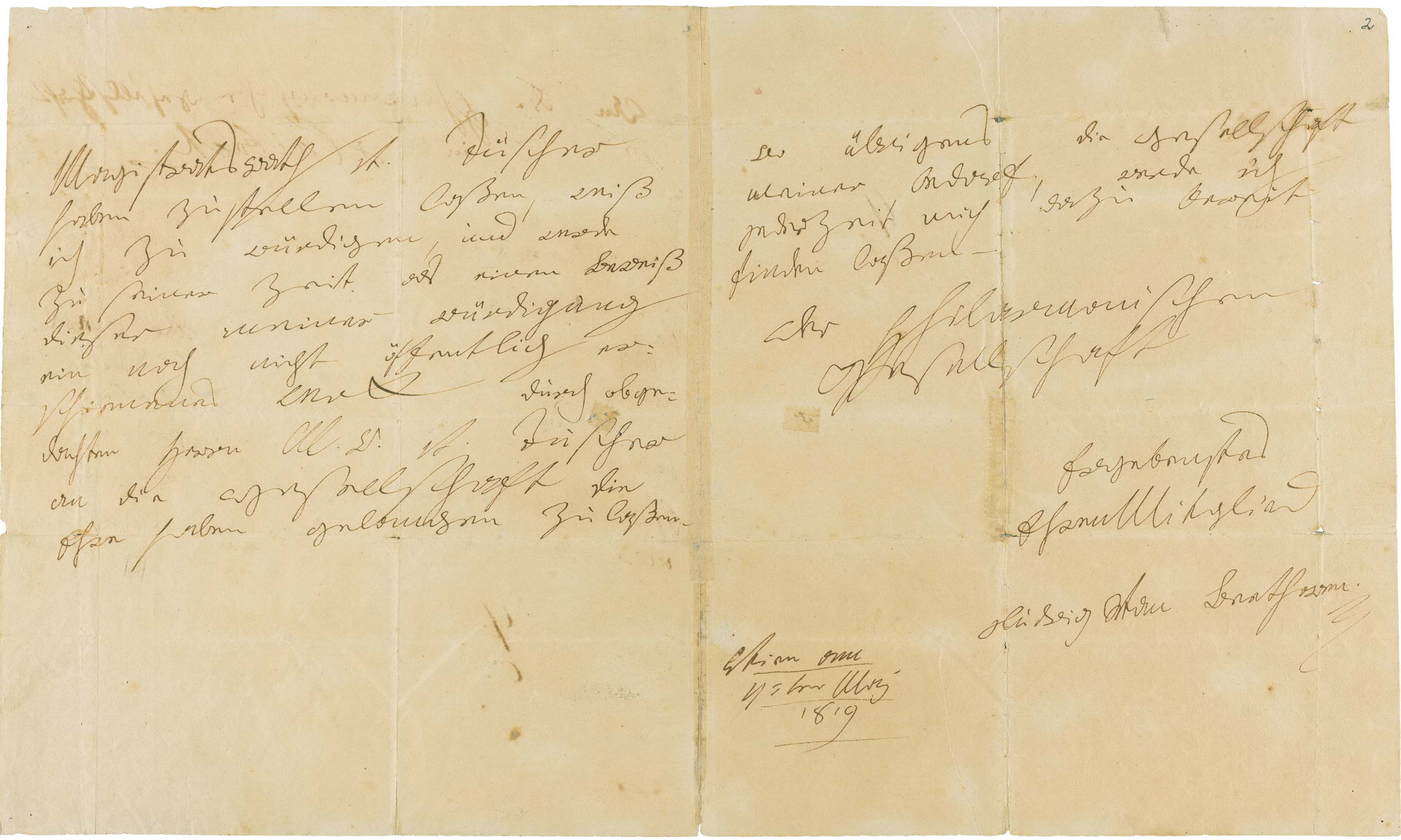

301 
Der Philarmonischen Gesellschaft

Ergebenstes EhrenMitglied

Ludwig Van Beethowen.

Wien am 4:ten Maj I8I ${ }^{34}$

Also informed about this turn of events were readers of Illyrisches Blatt in its supplement Laibacher Zeitung:

Für alle Mitglieder der Laibacher philharmonischen Gesellschaft, ibre Gönner und Freunde dürfen es angenehm seyn, $z u$ wissen, daß besagte Gesellschaft den berühmten Ludwig van Beethoven, dessen clasissche Compositionen die Laibacher Muiskfreunde in so vilen musicalischen Accademien bewunderten, sich zum Ehrenmitgliede erwählt und demselben das Diplom übersendet haben. Dieses Diplom wurde von Seiten der großen Componisten nicht nur sehr gütig aufgenommen, sondern es erfolgte hierüber auch noch eine eigenhändige, ungemein erfreuliche Rückantwort des Inhalts, daß dieser berühmte Tonkünstler das Diplom der Laibacher philharmonischen Gesellschaft als einen, ehrenvollen Beweis von den Anerkennung seiner (wie es sich bescheiden ausdrückt, geringen -) Verdienste

34 'To the Philharmonic Society in Ljubljana.

Honorary proof imparted to me by the honorable members of the Philharmonic Society as recognition to my trifling merits for music, to have elected me their honorary member and handed me the diploma through magistrate councilor Tuscher, I can value and shall send at earliest convenience as proof of my respect the society through the mentioned mister magistrate councilor Tuscher a work of mine, yet unpublished - Where the society should otherwise require me, I will always be at disposal.

Philharmonic Society's

most loyal honorable member

Ludwig van Beethoven.

Vienna 4 May I8I9'

'Ludwig van Beethoven, Brief an die Philharmonische Gesellschaft in Laibach, Wien, 4. Mai I819, Autograph. ansehe und daß die Gesellschaft jederzeit auf seine freundschaftliche Gesinnung rechnen dürfe. ${ }^{35}$

Beethoven's letter was met with a rather unusual historic fate. In the beginning, it was the first chronicler of the Society, the well-known Ljubljana doctor Friedrich Keesbacher, ${ }^{36}$ who drew attention to it when he published the chronicle of the Philharmonic Society in $1862 .{ }^{37}$ It was in the archive of the Philharmonic Society that Beethoven's letter had held an honorary place for several decades, until being sold along with numerous other valuables in a new post-war cultural-political reality of the south-Slavic state in which the Society could no longer operate in its previous form. First, it was sold to Switzerland, to the Zürich collector Hans Conrad Bodmer, and in 1956 to the Beethoven archive in Bonn,$^{38}$ where the letter is kept today. ${ }^{39}$

Electing Beethoven as an honorary member had surely contributed significantly to the rise of Philharmonic Society's repute. Although an early attempt to do so did not succeed, up until Beethoven's naming in I819, it did not arrive late, by international standards. The famous Society of Friends of Music (Gesellschaft der Musikfreunde) in Vienna, for instance, elected Beethoven its honorary member just three years before

35 'To all the members of Ljubljana Philharmonic Society, their supporters and friends, it will be pleasant to know that the mentioned society has elected as an honorary member: the well-known Ludwig van Beethoven, whose classical compositions have been admired in many academies by the Ljubljana friends of music, and sent him a diploma. Not only did the great composer receive this diploma but answered in his own hand extremely kindly that he accepts it as honorary proof of recognition of his (as he humbly put it, small) merits, and that the society can always count on his friendly affinity.' Kuret, Ljubljanska filharmonična družba, 5 I.

36 Zvonka Zupanič Slavec, Zgodovina zdravstva in medicine na Slovenskem: medicina skozi čas, javno zdravstvo, farmacija (Ljubljana: Slovenska matica, 2017), 110, 122.

37 Keesbacher, Die philharmonische Gesellschaft in Laibach, 5 I

38 Klemenčič, 'Beethovnova 6. simfonija in zveze z Ljubljano', 97-8.

39 'Ludwig van Beethoven, Brief an die Philharmonische Gesellschaft in Laibach, Wien, 4. Mai I819, Autograph.' 
its older Ljubljana 'relative'. Certainly though, Beethoven's election as an honorary member of the Philharmonic Society in Ljubljana importantly echoed both at home and abroad, and influenced the activity of the Society up until its informal end on 19 July 1921, when the Society was annexed, as the Philharmonic Association, with the Ljubljana Music Society (Glasbena matica)..$^{40}$

\section{Beethoven's symphonies on concert programmes of the Philharmonic Society in Ljubljana}

Since a substantial part of the archive of the Philharmonic Society in Ljubljana was not preserved, ${ }^{41}$ the image of Ljubljana's Philharmonic Society and, through it, performance of Beethoven's symphonies in Ljubljana can be reconstructed based on remaining preserved concert programmes and music catalogues..$^{42}$ The annual reports (Jahresbericht), published by the Philharmonic Society from 1862 onward, ${ }^{43}$ certainly also contribute to a clearer conception of individual academies' organisation of concert seasons, and their frequency. In the Music Collection of the National and University Library in Ljubljana, where the material related to the Ljubljana Philharmonic Society is kept, four music catalogues of the society are preserved. The first, already mentioned, is from 1804 . From the more

40 Kuret, Ljubljanska filharmonična družba, 443.

4I Jernej Weiss, 'Načrtna ukinitev Filharmonične družbe v Ljubljani in njen zadnji glasbeni ravnatelj Hans Gerstner', in Jernej Weiss, Hans Gerstner (I85I1939): żivljenje za glasbo (Maribor: Litera in Univerza v Mariboru, 2010), 6774. See also: Jernej Weiss, Česki glasbeniki v Ig. in na začetku 2o. stoletja na Slovenskem (Maribor: Litera in Univerza v Mariboru, 2012), 200

42 Sara Železnik, Repertoarne smernice Filharmonične družbe v Ljubljani: katalogi muzikalij Filharmonične družbe (Ljubljana: Znanstvena založba Filozof ske fakultete, 2014).

43 These are organised chronologically, with detailed list of all important events, not just concerts but also organisational meetings, membership deaths, different receptions, excursions, reports on music school activity, while at the end the membership list is enclosed, the society direction listed, and the financial report given. recent period, three more are found: the oldest among them is from 1898 , the second from 1904, while the youngest one in slip form, its date of origin unknown, seems to have been made after $1914 .{ }^{44}$ While the notes from catalogues, sheets, and concert programmes are often deficient, ${ }^{4}$ we can reconstruct a fairly precise image of performances of Beethoven's works for the Philharmonic Society. These were, for the most part, met with favourable reception with the Ljubljana audience, and Beethoven soon became the Philharmonic Society's 'house' composer, whose memory it honoured with particular solemnity in certain jubilee concerts. ${ }^{46}$

It is evident from the concert programmes that, until the founding of the central Slovenian musical institution Glasbena matica in 1872, Symphony no. 2 in D major was the one of Beethoven's symphonies which was most often performed in the Philharmonic Society's concerts, namely thirteen times. Following it are the First (with eleven performances) and the Seventh Symphony (with nine) and the Pastoral Symphony (with seven), whereas the remaining symphonies by Beethoven were performed much more seldomly. Among them, only Symphony no. 5 in $C$ minor (with four) exceeds two performances, ${ }^{47}$ while a performance of the Ninth Symphony cannot be traced in the mentioned period at all. As already mentioned, in $19^{\text {th }}$ century as well - according to the performing capacities of the Society on each occasion - individual symphony movements were performed more often than entire symphony cycles in concerts of the Ljubljana Philharmonic Society.

44 Sara Železnik, 'Kompozicije Ludwiga van Beethovna na koncertnih sporedih in v arhivu muzikalij ljubljanske Filharmonične družbe,' Muzikološki zbornik 48 , no. I (2012a): 52 .

45 Most frequently appearing in notes is only the mark Sinfonie (and similar versions of its writing) and the composer's surname. Thus often, neither opus no key are noted, whereas in some places not even the author is mentioned. Same goes for some vocal points, for example written Arie für Sopran with no author, and several times only the aria title without naming of its source work. Ibid., 5 I.

46 Železnik, Koncertni sporedi Filharmonične družbe 1816-1872, 21-365.

47 Kuret, Ljubljanska filharmonična družba, 474-626. 
Of Beethoven's other compositions, most often performed were the overtures Prometheus (2I times), Fidelio (14 times) and Egmont (13 times), while Adelaide and The Glory of God stand out among the songs. One must also mention the Septet in E flat major and the oratorio Christ on the Mount of Olives, individual parts of which were performed often, and it was surely performed as a whole at least thrice. ${ }^{48}$

After 1830 , the symphonies almost entirely disappeared from the Philharmonic Society's concert programmes. The main reason for this appears to be the greater and bigger supremacy of Italian opera repertoire, conditional on simultaneous change in receptive expectations of the audience. These dictated after 1830 , even in concert programmes of the Philharmonic Society, an almost complete changing of the compositions of the Viennese classics with works by Italian opera masters. Performances of symphonic compositions are thus most rare until the beginning of 18505 - they were mostly replaced by individual overtures and other opera excerpts, also resulting in rarer performances of Beethoven's symphonies.

If his works were practically a constant feature of the Philharmonic Society's concert programmes between 1817 and I 825 - performed on average even in ten and more concerts annually - this number strongly decreased with the start of I830s. That is why only one or two titles of Beethoven's works a year can be found in the Philharmonic Society's concert programmes from that decade onward. Among the exceptions is the Pastoral symphony, which, as it seems, points to the particular significance it had for Ljubljana: on 2 April I84I, its first movement was performed, and on I8 February 1842 the Andante. Then, on 8 November 1844, the full Beethoven's Symphony no. 7 in A major was exceptionally on the programme. Between I85I and I858, when symphonies had again become a constant feature of the Philharmonic Society's concert pro-

48 On 8 November I822, 6 April I852 and I8 March I856. (Železnik, 'Kompozicije Ludwiga van Beethovna na koncertnih sporedih in v arhivu muzikalij ljubljanske Filharmonične družbe,' 52 ). grammes, symphonic works by Mozart and Beethoven gradually started to prevail again. ${ }^{49}$

In addition to academies, the Philharmonic Society also organised many other events that stood out from the usual concert practice. The difference mainly shows in the reasons for such events, including these intended for celebrating the ruler's birthday or name day and more important national holidays, as well as commemorating important anniversaries of composers whose work was tied to the Society's activity. Events in connection with Beethoven echoed with special significance in this reference. Only a few days after the composer's death, two reports on Beethoven's illness and death were published in the leading Ljubljana newspaper of the time, Laibacher Zeitung.

On 30 March 1827, four days after the news about Beethoven's death had echoed in the Habsburg capital, a report from Vienna was published on the front page of the mentioned Ljubljana daily, dated 2I March 1827. It reports on the condition of Beethoven's poor health, and written as follows:

Unser Beethoven liegt beynahe schon volle vier Monathe an einer äußerst langwierigen und schmerzhaften Krankheit, der Wassersucht, darnieder, welche, wenn sie nicht sein Leben bedroht, ihn doch für lange Zeit in der Thätigkeit seines regen Geistes hindern dürfte. Kaum erfubr man in London den traurigen Zustand dieses hochgefeyerten Meisters, als einer seiner wärmsten Freunde und Verehrer, Hr. [Ignaz] Moscheles, mit regem Eifer die Sache der dortigen philharmonischen Gesellschaft vortrug, welche dann in einer großen Versamm-lung einstimmig beschloß, ihn nicht nur für den Augenblick, sondern auch für die Zukunft mit allem zu unterstützen, was er nur immer bedürfe. In Folge dessen ließ die Gesellschaft Hrn v. Beethoven durch das Haus Rotschild einstweilen rooo fl. übermachen, mit dem Beysatze, nichts zu sparen, was ihm seine Gesundheit, und damit wieder sein freyes Wirken im Reiche der Töne verschaffen könne. - Mit welcher innigen

49 Železnik, Koncertni sporedi Filharmonične družbe 1816-1872, 15. 
Rührung Beethoven diese edelmüthige Handlung vernahm, läßt sich wohl kaum beschreiben, und hätten, die würdigen Männer in London davon Zeugen seyn können, so würde dießschon allein hinreichende Belohnung für sie gewesen seyn. Beethoven ist in ärztlicher Hinsicht in den besten Händen. Seine Umgebung besteht aus seinem Jugendfreunde, dem kais. königl. wirklichen Hofrathe von Breuning, und seinem vieljährig erprobten Freunde, Hrn. Musikdirector [Anton] Schindler, der ihm mit aller Aufopferung die Dienste eines wahren Freundes erweiset. Möge es der Vorsehung gefallen, uns und der gesammten Kunstwelt diesen Heros der Tonkunst noch lange zu erhalten. ${ }^{50}$

On 3 April 1827 - a week after Beethoven's death - the paper also summarised the sad news from the Habsburg capital on the front page:

Die Hoffnungen und Wünsche, welche die zablreichen Freunde und Verehrer Beethovens für die Wiederherstellung dieses groBen Künstlers gehegt hatten, sind leider nicht in Erfüllung gegangen.

50 'Due to an exceptionally long illness, our Beethoven has been confined for full four months to his bed. He fell ill of dropsy that will, if not endanger his life, long hinder him in the activities of his lively spirit. In London, they found out about the sad state of this most famous master when one of his closest friends and admirers Mr. [Ignaz] Moscheles, presented the matter with great fervour to the philharmonic society there. The latter afterwards concluded unanimously in a large gathering that it will not only for the moment but also in the future support him with anything he might need. As a consequence, the society donated with support of house Rothschild I000 guldens to Beethoven at this time with a postscript not to spare on with anything which would attain him health and with it again free engagement in the kingdom of tones. - With what inner affection Beethoven found of this noble deed can probably hardly be described, and if the distinguished men from London could have witnessed it, it would already itself be a sufficient reward for them. Beethoven is in the hands of best doctors. Surrounded by his friends of youth, c. k. court councillor von Breuning and his friend tested through many years, musical director Mr. [Anton] Schindler, who has in all unselfishness attested him favours of a true friend. That only it would please Providence to preserve to us and entire artistic world this hero of tonal art for yet a long time at life.' Laibacher Zeitung, no. 26, 30 March I827, IOI.
Ludwig van Beethoven unterlag am 26. d. M. Nachmittags zwischen 5 und $6 \mathrm{Uhr}$ der langen und schmerzhaften Krankheit, an welcher er seit mehreren Monathen gelitten hatte. - Sein Leichenbegängniß wird morgen, den 20. d. M. Nachmittags 31/2 Uhr, von seiner Wohnung im Schwarzspanierhause aus, Statt finden. ${ }^{\text {s }}$

Among the most echoing events later dedicated to the memory of Beethoven by the Ljubljana Philharmonic Society was the $100^{\text {th }}$ anniversary celebration of Beethoven's birth in 1870 . The Philharmonic Society in Ljubljana honoured the memory of its most important honorary member with two concerts on 12 and ${ }_{3}$ November 1870.

The Society had been preparing for the event for some time. They founded several committees for better organisation. The honorary committee was chaired by Anton Schöppl, Land Councillor and the later knight Von Sonnwalden who had been leading the Philharmonic Society in an administrative capacity as its director since 1859, the appointment by the then mayor of Ljubljana Josef Suppan, and in the artistic capacity by the musical principal of the Philharmonic Society at the time, Anton Nedvĕd..$^{52}$

Performance was given no small attention, since they had to obtain singers and orchestra members from outside of Ljubljana as well. There were 60 Ljubljana singers (of them 40 men), 40 male and I 2 female singers arrived from Celje, seven singers from Kočevje, two both from Trieste and from Maribor, and three singers from Gorizia. The most guests

5I 'The hopes and wishes nurtured by numerous friends and admirers $f$ Beethoven for this great artist's recovery sadly did not come to pass. Ludwig van Beethoven succumbed on the $26^{\text {th }}$ of this month between 5 and 6 p.m. to a long and painful illness of which he had suffered for month - Procession to the churchyard will start tomorrow, on the $29^{\text {th }}$ of this month in the afternoon at 3.30 from his [Beethoven's] apartment on Schwarzspanierhause.' Laibacher Zeitung, no. 27, 3 April 1827, 105.

52 Siebenter und Achter Jahresbericht der philharmonischen Gesellschaft in Laibach pro I 869 \& 1870 (vom I. Jänner I 869 bis letzten September I870 und vom I. October I870 bis letzten September I87I) (Laibach: Verlag der philharmonischen Gesellschaft, I87I), 4. http://www.dlib.si/details/URN:NBN:SI:DOC-WFDGPLNO. 


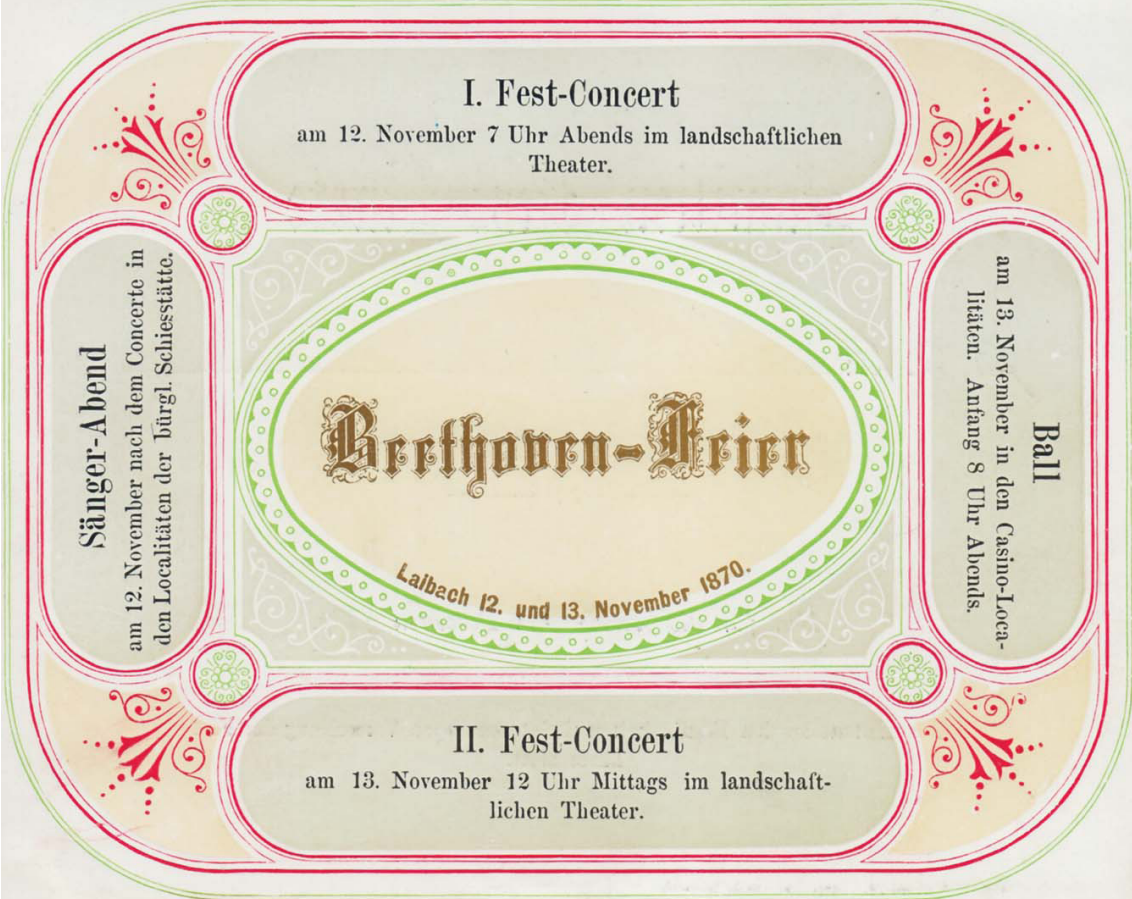

The programme and invitation for Beethoven's celebration (1870).

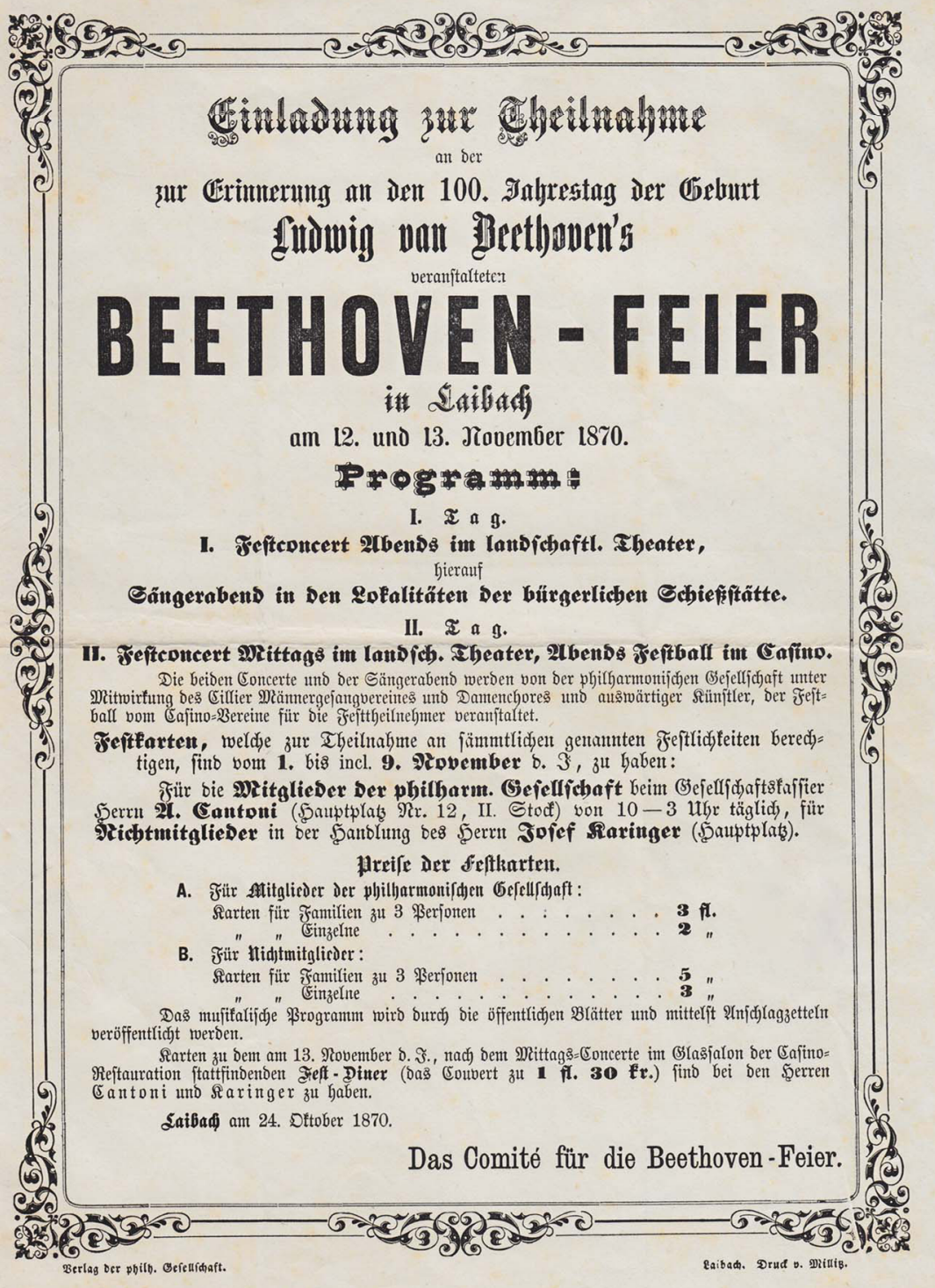


in the orchestra were from Graz and Zagreb (I2 together), one both from Trieste and from Maribor, and four from Carinthia. ${ }^{3}$

The concert began with a solemn prologue, prepared just for this occasion by Friedrich Keesbacher. Upon the final strophe of the introductory speech, Beethoven's bust was unveiled, richly decorated with flowers. The prologue was followed by the overture to the opera Fidelio, and afterwards the cantata for choir and orchestra Calm Sea and Prosperous Voyage (Meeresstille und glückliche Fahrt). The Trieste violinist Julius Heller then performed the Concerto for violin and orchestra in $D$ major, followed by the soprano concert aria $A$, perfido, sung by a member of the Land theatre Mrs. Frankenberg, then the Fantasia ('Choral Fantasy') for piano, choir and orchestra in C minor, in the performance of which the pianist Josef Zöhrer and singer soloists participated. After the Choral Fantasy, the male choir performed a choral arrangement of the soprano lied The Glory of God (Die Ehre Gotter), and the concert concluded with the closing chorus from the oratorio Christ on the Mount of Olives. ${ }^{54}$

The evening continued with a speech by Land Councillor Schöp$\mathrm{pl}$ about Beethoven and the meaning of his word for musical culture, they read the greeting messages from Klagenfurt and Maribor, after which a singing evening followed, where compositions of other composers were performed, not only Beethoven's. The first part of the celebration of Beethoven's birth was met with favourable echoes, above all in the Laibacher Zeitung newspaper, which paid special attention to the event and quoted Grillparzer's speech at Beethoven's funeral in its feuilleton, ${ }^{55}$ then reported two days later on the two concert evenings. ${ }^{56}$ The audience was said to have accompanied each performance with booming applause and great enthusiasm. An unsigned critic separately point-

53 Železnik, 'Kompozicije Ludwiga van Beethovna na koncertnih sporedih', 57.

54 Kuret, Ljubljanska filharmonična družba, 169-70.

55 Laibacher Zeitung, no. 259, I2 November 1870, I855-56.

56 Laibacher Zeitung, no. 260, 14 November 1870, 1865-66. ed out the exceptional performance of the violinist Heller and wrote about him:

Den Glanzpunkt des Concertes bildete aber unstreitig des Violinconcert, vorgetragen von Herrn Heller. Wir haben in Herrn Heller einen vollendeten Künstler kennen gelernt. Diese Leichtigkeit des Bogens, diese Reinheit, Klarheit und Schmiegsamkeit des Tones, diese perlende Anmuth der Passagen können nur die Resultate eines ausgebildeten großen Talentes sein. ${ }^{57}$

On 13 November, the second day of Beethoven's celebration followed, starting with a joint rehearsal of all participants. First performed in the concert was Beethoven's Symphony no. 5 in $C$ minor, next was a performance of the lieder Mignon and New Love, New Life (Neue Liebe, neues Leben), interpreted by soloist Leopoldina Gregorič, as well as the lieder Remembrance (Andenken) and With a Painted Ribbon (Mit einem gemalten Band) performed by Alexander Rüdinger, a member of the Land theatre. They closed the concert with the performance of the cantata The Ruins of Athens (Die Ruinen von Athen) for soloists, choir, and orchestra. A festive lunch for participants followed after the concert, in addition to which they held a ball at 9 p.m. in the solemnly decorated Kazina..$^{58}$

The reporters were particularly thrilled about the performance of Beethoven's Symphony in C minor. Additionally the anniversary of Beethoven's birth revealed in the performing field above all the personality of conductor Anton Nedvĕd who was certainly the one most deserving of a successful execution of musical performances. For him, the Beethoven celebration surely represented one of the performing pinnacles in his career.

57 'The peak of the concert was without doubt the Violin Concerto performed by Mr Heller, in whom we recognized the perfect artist. Such lightness of bow handling, this purity, clarity, and willingness of tone, pearly whites of the passages can only be the result of a shaped great talent.' Ibid., I865.

58 Kuret, Ljubljanska filharmonična družba, I70. 
Also present at these events was the composer's biographer, U.S. consul in Trieste Alexander W. Thayer, who published an article about the celebration in the Society's annual report, dated is November $1870 .{ }^{99}$ The Philharmonic Society has gained, upon the big success of Beethoven's festivity, self-confidence in its own forces and also proved itself capable of organising more extensive musical shows as well. For Ljubljana, Beethoven's $100^{\text {th }}$ anniversary in the $19^{\text {th }}$ century was thus definitely one of the more important events that long resounded.

Compositions of Ludwig van Beethoven, however, were not only topical in the solemn days, but had practically had a special status also in regular academies of the Philharmonic Society, the central concert institution in the $19^{\text {th }}$ century in Slovenia. In its highly rich performing history, a series of other significant Beethoven memorial concerts followed. Therefore, the repertory of the Philharmonic Society in Ljubljana appears, in regard to first performances of Beethoven's symphonies, entirely comparable with some of the most important foreign concert institutions of the time.

However, Beethoven's meaning for Ljubljana was, of course, not limited merely to his compositions, performances of which had also attracted many renowned foreign musical performers to these parts. After all, it was exactly such honorary memberships, solemn academies, and other resounding events in the exceedingly rich performing history of the Ljubljana Philharmonic Society that have in considerable measure defined the cultural conscience of the then young Biedermaier bourgeois culture, and connected Ljubljana with some of the most important musical centres of the Habsburg monarchy. From there springs also the necessary self-conscience of certain key protagonists of the activity of the Philharmonic Society in Ljubljana. It is thanks to them that the Carniolan capital, despite its relatively small size, became an important constituent part of the most up-to-date European musical currents at the time.

59 Siebenter und Achter Jahresbericht der philharmonischen Gesellschaft in Laibach, 6-14. 